\title{
Effects of Internal Controls, Fraud Motives and Experience in Assessing Likelihood of Fraud Risk
}

\author{
Zuraidah Mohd-Sanusi, Norhayati Mohamed, Normah Omar, and Mohd-Daniel Mohd-Nassir
}

\begin{abstract}
The audit profession has attempted to improve auditors' ability in assessing likelihood of fraud risk so as to enhance audit quality and increase investor confidence. Malaysian Approved Standards on Auditing, AI 240 on "Fraud and Error" and National Audit Department guidelines on fraud requires the auditor to assess the likelihood of fraud based on the internal control and pressure and opportunity. The purpose of this study is to examine which factor most likely use by auditors in assessing the likelihood of fraud risk. An experimental approach is adopted by sending case scenarios to 63 auditors from the National Audit Department of Malaysia and 67 final year accounting students. Both groups have to complete two different case scenarios which level of internal controls and fraud motivation (i.e., pressures and opportunity) are being manipulated into high and low level. The results indicate that there are significant interaction between internal controls and fraud motivation factors. The findings may provide insights into the auditors' judgment in fraud risk assessment which could be beneficial to increase the auditors' awareness and understanding of fraud risk factors and thus, maintain their viability in the auditing profession.
\end{abstract}

Index Terms-Assessment of fraud risk, fraud triangle, internal control, audit judgment. fraud motives.

\section{INTRODUCTION}

Fraud became a challenge in managing organization regardless the type of industries and Malaysia is equally affected. In fact fraud risk differ from each type of industries and required different prevention actions [1].

Failures to prevent and detect fraud have serious consequences to organizations. Survey done by [2] estimated that the typical organization loss $5 \%$ of its revenues to fraud each year, approximately $\$ 3.5$ trillion from the $\$ 70.28$ trillion 2011 Gross World Product. However fraud can be minimized by putting management control system features such as internal control which is commonly regarded as a key deterrent of fraud.

Although internal control is a key deterrent of fraud, there

Manuscript received September 17, 2013; revised November 18, 2013 This work was supported in part by the Malaysian Ministry of Education (MOE).

Z. Mohd-Sanusi is with the Accounting Research Institute and Faculty of Accountancy, Universiti Teknologi MARA, 40450, Shah Alam, Selangor, Malaysia (e-mail: zuraidahms@ @alam.uitm.edu.my).

N. Mohamed was with the Universiti Teknologi MARA. She is now with the Ministry of Education, Putrajaya, Malaysia (e-mail: norhayati.mohamed@mohe.gov.my).

N. Omar is with the Accounting Research Institute, Universiti Teknologi MARA, 40450, Shah Alam, Selangor, Malaysia (e-mail: normah645@salam.uitm.edu.my).

M. D. Mohd-Nassir is now with the Faculty of Accountancy, University Teknologi MARA, 40450, Shah Alam, Malaysia, on leave from the Malaysian Audit General Office, Putrajaya, Malaysia (e-mail: daniel_nassir@yahoo.com). is incident where the frauds still occur even though the internal control is strong. Vice versa, the weak of internal control does not mean the fraud could be occurring.

Internal control and fraud triangle have the advantage in detecting the fraud, however understanding the fraud triangle can improve the ability to detect the likelihood of fraud risk [3]. This being mentions in paragraphs 24 of ISA 240, where the auditor should evaluate whether one or more fraud risk factor are present. Likewise, the public sector fraud guidelines also mention the fraud motivation factor need to give an attention.

\section{A. Research Question and Objective}

In Malaysia Public Sector Auditing, the fraud guideline requires the auditor to assess the fraud risk during the conduct of the audit. Even though is not auditor responsibility, they still required to maintain an attitude of professional skepticism which involves maintaining an attitude that includes a questioning mind, being alert to conditions which may indicate possible misstatement due to error or fraud, and a critical assessment of audit evidence.

Auditor still needs to use their professional judgment and experience in assessing the likelihood of fraud risk based on the factor they have faced during the audit. Inability to assess the fraud risk with accurate can cause the fraud being not detected. Therefore [2] survey reveal that the external auditors only detect $3 \%$ of the fraud reported to them.

This study will assess whether internal control factor and fraud motives influence auditors in assessing the likelihood of fraud risk. Therefore, the research questions arise for this study is to what extent the auditors use the internal control framework and fraud triangle element in assessing the likelihood of fraud risk. Secondly, this study will examine whether the auditor and accounting student have the same direction in assessing the likelihood of fraud risk.

Specifically, this study focused on achieving the following objective:

To examine the interaction effect of internal control framework and fraud triangle element (i.e. pressure and opportunity) in assessing the likelihood of fraud risk.

- To examine whether internal control framework or fraud triangle element (i.e. pressure and opportunity) as a main effect in assessing the likelihood of fraud risk.

- To investigate whether auditor and student have a different perspective about internal control framework and fraud triangle element (i.e. pressure and opportunity) in assessing the likelihood of fraud risk.

\section{DiscusSION OF PREVIOUS WORK}

\section{A. Ability in Assessing the Likelihood of Fraud Risk}

Detection of fraud is not the primary responsibilities of the 
auditor. However auditor required maintaining an attitude of professional skepticism, therefore they need to develop the ability in assessing the likelihood of fraud risk. Auditors being trained to understand the internal control framework and using it during the implementation of audit. Even though auditor understand the internal control framework, the detection of fraud by the external auditor still at $3 \%$ from the reported fraud incidence [4]. Therefore, auditors need to improve the ability in assessing the likelihood of fraud risk to stay relevant in the industries.

Auditor need to view fraud not only from the internal control perspective but also from the criminologist perspective of view. In other word, auditor needs to understand why people commit fraud. From the criminologist perspective, fraud occurs when pressure, opportunity and rationalization present individually or collectively. Combination of this three factors also known as a fraud triangle. Understanding of fraud triangle can help the auditor to make a better fraud risk assessments. Furthermore, no specific guideline mention the most significant internal control red flag indicator in detecting fraud, due to this auditor may assume all the indicators are equally important [5]. The use of red flag alone is not enough as a tool in fraud detection, auditor need to understand the fraud triangle in assessing the likelihood of fraud risk.

Experience in auditing also can help auditor improving the ability in assessing the likelihood of fraud risk. This is because auditors with more auditing experience are more exposed with the fraudulent activities during performing the audit. With this experience, they develop the ability in assessing the likelihood of fraud risk. Further investigation show that, there is no difference between internal and external auditor when they assess the likelihood of fraud risk [6]. Therefore junior auditor need to expose as much as possible during the performance of audit and supervised by the senior auditor. With this the auditor will gain the real experience in assessing the likelihood of fraud risk.

\section{B. Internal Control Framework}

Internal control can be a key deterrent to organizational for minimize the fraud risk. Internal control can be defined as a process, affected by an entity's board of directors, management and other personnel, designed to provide reasonable assurance regarding the achievement of objectives in (1) the effectiveness and efficiency of operations, (2) the reliability of financial reporting, and (3) the compliance of applicable laws and regulations. Thus, a system of internal controls potentially prevents errors and fraud through monitoring and enhancing organizational and financial reporting processes as well as ensuring compliance with pertinent laws and regulations [7]. Therefore, organization have to address fraud risk in a robust manner so the internal control structure can be effective [1].

One of the factor may influence the auditor assessment of the fraud risk as high, is management failure to display appropriate attitude towards internal control. The failure of management will cause the greater risk for the going concern of the organization. When management demonstrate the importance of good internal control within an organization, the fraud risk can be reduced [5]. This shows that an auditor have a same direction that weak of internal control as one of the factor in the cause of fraud.

However poor internal control alone does not have a stronger association with the incidence of fraud but the combination effect of low perceptions of organizational justice and poor internal control have more stronger association [7]. Management have to review and rectify the internal control procedure frequently, infrequent review of internal control may increase the fraud risk to be occurred. If the internal control not being review for such a long time, the fraudster can identified and exploited the weaknesses in internal control [8]. Plus one survey done by audit firm also supported the weaknesses of internal control as a factor fraud being committed [9], [10]. Therefore, auditor will assess the likelihood of fraud risk from the perspective of internal control framework rather than perspective of fraud triangle.

\section{Fraud Triangle}

Fraud triangle is not contradicting with the internal control framework and emphasize into three different elements. These three elements more focus to the individuals who could have the opportunity in committing the fraud [3].

Opportunity can be described as a situation where poor internal control in the organization can be manipulated by the employee to commit, conceal and avoid to be punished [7]. While [11] find that "opportunity red flags" is the top five important indicator for internal and government auditors. Opportunity being look as an influences to the distribution of criminal behavior, for example if the employee have the financial pressure but thus not have the opportunity then the fraud could not be happens probably high. It was the fraudster knowledge and expertise to an able them bypass controls and create an opportunity. With the trusted relationships created the opportunity to commit fraud become more easier to the fraudster [8]. Even though we have separation of duties in the internal control framework to deter asset misappropriation, employees would willingly collude with one another to create the opportunity to commit fraud [3]. To assess the fraud risk, auditor need to understand the opportunity in the fraud triangle because opportunity allow fraudster to seek a solution through illegitimate means [8]. Plus the previous research [5], [11] also suggesting the opportunity is the important element when assessing the fraud risk.

Even the opportunity is among the top important indicator, pressure and rationalization also important this is because element of fraud present collectively [3]. Therefore auditors also need to understand the element of pressure, which is focus more to the individual as suggested by [3]. Individual can become a big threated to the organization if they perceived the organization treat them unfairly. Poor perception of organization justice can increase the employee pressure retaliate through employee fraud. This also can be a reason or rationalization of the employee why they committing the fraud [7]. So the pressure also needs to be considered by the auditor when assessing the likelihood of fraud risk.

Hence, the auditor should more focus to the fraud triangle element because people commit the fraud. Book and records cannot lie without the intervention of the people. Even though internal control framework covers all the element for having the effective and efficient internal control system, there is no ham for auditor to view a fraud problem from the 
perspective of fraud triangle.

\section{Hypotheses Development}

As part to form the opinion in the financial audit, external auditor required to attest the clients internal control effectiveness. Internal control assessment would be part of the audit engagement to make sure internal control is effective and sufficient to deter fraud risk in the organization. Auditor need to understand client's internal control for them to assess the audit risk. If the internal control were rated as weak, audit risk would be increased and this will make the auditor to plan the audit more rigorous to make sure they do not miss any material misstatement due to error or fraud and vice versa. The use of appropriate audit techniques can assist auditor in identify the weaknesses of internal control and able to detect the likelihood of fraud risk [6]. However to use internal control framework alone in the assessing the fraud risk is quite difficult because auditor need to understand every element in the internal control framework [3]. Therefore, auditors need to view the fraud problem from the perspective of fraud triangle as well to increase the ability in assessing the likelihood of fraud risk. Detection of $3 \%$ of fraud incidence by the [2] did not mention whether external auditor assessing the fraud risk from the perspective of fraud triangle or from the perspective of internal control framework. However, due to nature and the training given to the auditor, they still view the fraud problem from the perspective of internal control framework [3]. Auditor will use and consider internal control framework more than fraud triangle element. Based on this the first hypotheses will be:

$H_{1 a}=$ Internal control framework as a main effect in assessing the likelihood of fraud risk.

$H_{1 b}=$ Fraud triangle (i.e. pressure and opportunity) as a main effect in assessing the likelihood of fraud risk.

Combination of internal control framework and fraud triangle can made fraud risk assessment easily to be formulated. Red flags indicator can be a most beneficial tools to auditor or management in assessing the fraud risk but this were ignored by management [8]. However the internal control more focuses to the procedure and the system. While fraud triangle suggests the focus should be align to the people who have the potential to commit fraud rather than focusing on the organization alone [3]. Combination internal control framework and fraud triangle should increase the ability of the auditor in assessing the fraud risk. Based on this argument we develop the following hypotheses:

$\mathrm{H}_{2}=$ Internal control framework has an interaction effect with fraud triangle (i.e. pressure and opportunity) in assessing the likelihood of fraud risk.

As discuss earlier, experience also playing part for the auditor in assessing the likelihood of fraud risk. Auditor in the industries already being trained and exposed to the varieties of fraud risk, while student in accounting only received the knowledge about the fraud risk through the discussion or learning session. Exposure to the fraud triangle to both will make the ability in assessing of the likelihood of fraud risk increase. However auditor more reluctant to adopt the fraud triangle alone in assessing the fraud risk because of the exposure they have compare to the student [3], [11]. Therefore the third hypotheses will be:

$H_{3}=$ Auditor and student have a different perspective about internal control framework and fraud triangle element (i.e. pressure and opportunity) in assessing the likelihood of fraud risk.

\section{Methodology}

An experimental design being use in this study, independent variable being manipulated, internal control as one variable while fraud triangle element (i.e. pressure and opportunity) as one variable. We are dividing the group into four. Group 1 and group 2, received the case with high internal control framework but for fraud triangle element (i.e. pressure and opportunity) group 1 received the high fraud triangle element (i.e. pressure and opportunity) while group 2 received the low fraud triangle element (i.e. pressure and opportunity). Group 3 and group 4 received low internal control framework case but for the group 3 they received high fraud triangle element (i.e. pressure and opportunity) compare with the group 4 received low fraud triangle element (i.e. pressure and opportunity).

For government auditors, the research instrument being distributed to the head of participate branch for distribute to their subordinates. The branch being selected including branch perform the task as external auditors and branch perform the task as internal auditors. The type of auditor did not affect the ability in assessing the likelihood of fraud [6]. Even though there are in different branch, they still under the National Audit Department and received the same training from the department. While for the student, research instrument being distributed via the lecturer which is then distributed to the individuals students. Research instrument distributed to the government auditors being collected after two week of distribution. While for the student, the lecturer collected the research instrument during the end of class period. They are assured confidentiality of the answer.

One hundred sixty (160) research instruments were distributed and 152 were returned. Out of 152 instruments, 22 left a few items in the questionnaire incomplete. This makes the useable instrument only 130, representing $81.3 \%$ response rate. The responses rate is calculated as the percentage of the number of usable returned questionnaires to the number of questionnaires sent. From the 130 participants of the study, $63(48.5 \%)$ of them is the government auditors and $67(51.5 \%)$ is the final year student.

Case from [3] being modified to suit with the current study and added with the manipulation of the variables. Participants are instructed to read the case and give the judgment about the likelihood of fraud risk in the case. After they give the judgment related to the likelihood of fraud risk, they will answer 8 questions related to manipulation check. This manipulation check will make sure the treatments for the case are consistent with the information perceived by the participant. The participants also need to answer about their sex and race. Extra profile needed for the government auditor include academic qualification, professional membership, 
grade position and length of service. The instrument requires approximately 20 to 30 minutes completing.

Case 1 being manipulate perceive with the information of high internal control framework and fraud triangle element (i.e. pressure and opportunity). Even though the fraud factors are high, the internal control also high in order to deter the fraud.

While in case 2, variable of internal control framework still high but fraud triangle element (i.e. pressure and opportunity) are low. Information for internal control framework being manipulate for participant perceived it is high. While fraud triangle element (i.e. pressure and opportunity) being manipulated to perceive it is low. Participant should judge the likelihood of fraud is low because pressure and opportunity in this case is low.

In case 3 , the same case 1 being use but the internal control framework being manipulate as low while fraud triangle element (i.e. pressure and opportunity) as high. In this case the participant should judge the likelihood of fraud risk as high. This is because employee in pressure and have an opportunity to commit fraud since the internal control is minimal.

Case 4 adopt the case 2 but some modification being made in order to manipulate the internal control framework and fraud triangle element (i.e. pressure and opportunity) as low. Participant should judge the likelihood of fraud is medium. Even though the internal control in this case is low, pressure and opportunity in this case also low.

This study examines one dependent variable which is likelihood of fraud risk and two independent variables consist of internal control framework and fraud triangle (i.e. pressure and opportunity). Fraud risk is measured using the continuous scale. The scale use for measuring this variable is ranging from 1 (strongly unlikely) to 7 (strongly likely). Participants will use the professional judgment to answer every case present to them. Internal control framework being measured by categorical scale, 1 represent low internal control and 2 represent high internal control. While fraud triangle element (i.e. pressure and opportunity) being measured by the same scale of internal control framework it is categorical scale. 1 represent low pressure and opportunity and 2 represent high pressure and opportunity.

Manipulation check for the internal control framework and fraud triangle (i.e. pressure and opportunity) is measured using eight different questions. Four questions related to the internal control framework and another four related to the fraud triangle element (i.e. pressure and opportunity). The analysis of data is examined using the two way analysis of variance (ANOVA). This type of analysis is suitable because it allows the test the impact of two independent variables on one dependent variable. The advantage of using a two way ANOVA, it allows the test for an interaction effect, when the effect of one independent variable is influenced by another independent variable.

\section{RESULTS}

\section{A. Demographic of Participants}

Demographic characteristic of participants in this study are reported in TABLE I. Participants of this study consist of government auditor and the final year student, which is 63 (48.5\%) government auditors and $67(51.5 \%)$ final year student. Overall male and female participant is $33(25.4 \%)$ and $97(74.6 \%)$ each. More specifically, 21 male and 42 female came from the government auditor group while student group consists of 12 male and 55 female. For overall race composition, Malays dominance with 122 (93.8\%), Chinese $6(4.6 \%)$, Indian 1 and other ethnic is $1(0.8 \%)$ each. In student group, 67 participants came from the Malays ethnic while government auditor group consist of 55 Malays participant, six Chinese participants, one Indian participant and one from others ethnic.

TABLE I: DEMOGRAPHIC CHARACTERISTIC

\begin{tabular}{|c|c|c|c|c|}
\hline & \multicolumn{2}{|c|}{ Student $(\mathrm{N}=67)$} & \multicolumn{2}{|c|}{ Gov. Auditors $(\mathrm{N}=63)$} \\
\hline & Frequency & $\%$ & Frequency & $\%$ \\
\hline \multicolumn{5}{|l|}{$\underline{\operatorname{Sex}}$} \\
\hline Male & 12 & 17.9 & 21 & 33.3 \\
\hline Female & 55 & 82.1 & 42 & 66.7 \\
\hline \multicolumn{5}{|l|}{ Race } \\
\hline Malay & 67 & 100.0 & 55 & 87.3 \\
\hline Chinese & - & - & 6 & 9.5 \\
\hline Indian & - & - & 1 & 1.6 \\
\hline Other & - & - & 1 & 1.6 \\
\hline \multicolumn{5}{|l|}{ Academic Qualification } \\
\hline $\begin{array}{l}\text { Post Graduate Degree } \\
\text {. }\end{array}$ & - & - & 3 & 4.8 \\
\hline Bachelor Degree & - & - & 26 & 41.3 \\
\hline Diploma & - & - & 29 & 46.0 \\
\hline Certificate & - & - & 4 & 6.3 \\
\hline Others & - & - & 1 & 1.6 \\
\hline \multicolumn{5}{|l|}{ Membership } \\
\hline MIA & - & - & 8 & 12.7 \\
\hline IIA & - & - & 5 & 7.9 \\
\hline None & - & - & 50 & 79.4 \\
\hline \multicolumn{5}{|l|}{ Position grade } \\
\hline $48-54$ & - & - & 3 & 4.8 \\
\hline $41-47$ & - & - & 12 & 19.0 \\
\hline $27-40$ & - & - & 48 & 76.2 \\
\hline \multicolumn{5}{|l|}{ Years of services } \\
\hline Less 10 years & - & - & 39 & 61.9 \\
\hline $11-20$ years & - & - & 15 & 23.8 \\
\hline $21-30$ years & - & - & 8 & 12.7 \\
\hline Above 30 years & - & - & 1 & 1.6 \\
\hline
\end{tabular}

\section{B. Interaction Effect between Internal Control Framework} and Fraud Triangle in Assessing Fraud Risk

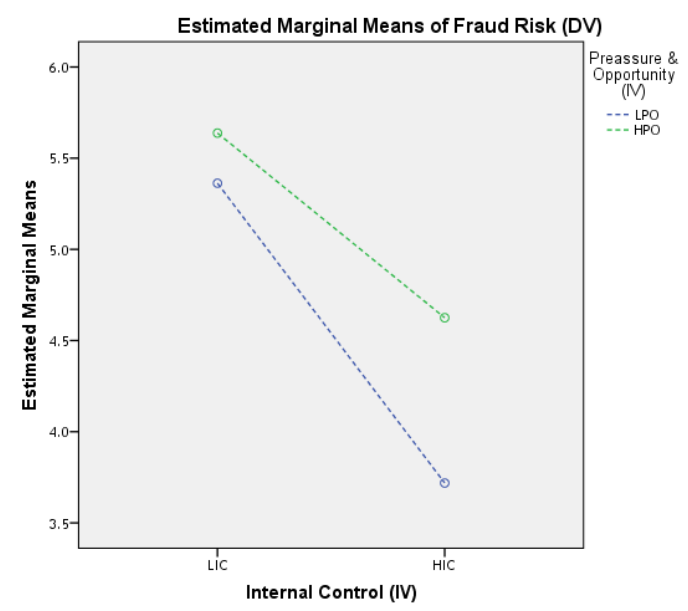

Fig. 1. Interaction between internal control framework and fraud triangle element. 
A two-way between-group analysis of variance was conducted to explore the impact of internal control framework and fraud triangle elements (i.e. pressure and opportunity) on auditor ability in assessing the likelihood of fraud risk. The interaction effect between internal control framework and fraud triangle element statistically significant, $F(1,252)=3.82, p=0.05$ therefore $H 2$ is supported. The Fig. 1 shows that in a condition of low pressure and opportunity, participants marked higher likelihood of fraud risk (mean = 5.38) when internal control is low as compared to internal control is high (mean $=3.72)$. Whereas in a condition of high pressure and opportunity, participants marked higher fraud risk assessment judgment (mean $=5.67)$ when internal control is low as compared to internal control is high (mean = 4.62).

\section{Main Effect between Internal Control Framework and Fraud Triangle in Assessing Fraud Risk}

Because the interaction exist between the internal control framework and fraud triangle element (i.e. pressure and opportunity), a one way between group analysis of variance was conducted to explore the impact of internal control framework on ability in assessing the likelihood of fraud risk. There was a statistically significant difference at the $p<0.05$ level in ability in assessing the fraud risk $F(1,258)=63.062$, $p=0.00$. Despite reaching statiscally significance, the actual difference in means score was large. The effect size, calculated using eta squared, was 0.19. While impact the fraud triangle element (i.e. pressure and opportunity) on ability in assessing the likelihood of fraud risk also statistically significant $F(1,258)=10.128, p=0.00$. However the effect size was small (0.04). Therefore internal control is a main effect in assesing the likelihood of fraud risk which is H1a and H1b being supported.

\section{Auditor and Student Perspective about Internal Control Framework and Fraud Triangle}

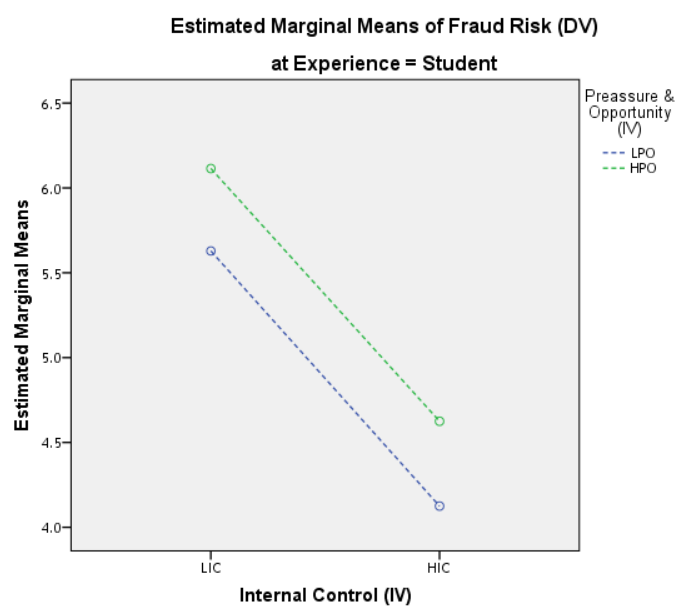

Fig. 2. Interaction between internal control framework, fraud triangle element and student.

An independent samples t-test was conducted to compare the likelihood of fraud risk for student and Gov. auditor. There was significant difference in scores for students $(M=$ $5.16, S D=1.424)$ and government auditor $(M=4.54, \mathrm{SD}=$ $1.573 ; t(251.5)=3.309, p=0.10$, two-tailed $)$. The magnitude of the differences in the means (mean difference $=62,95 \%$
CI: 0.250 to 0.984 ) was very small (eta squared $=0.04$ ). In detail, when fraud triangle element (i.e. pressure and opportunity) are low student marked the likelihood of fraud risk as high when internal control is low $(M=5.63)$. Student also marked the likelihood of fraud risk low when the internal control is high $(M=4.13)$. While in the scenario of high fraud triangle element (i.e. pressure and opportunity), student marked the likelihood of fraud risk high when the internal control framework low $(M=6.11)$. When internal control framework high, student marked the likelihood of fraud risk as low $(M=4.62)$ in high fraud triangle element (i.e. pressure and opportunity). The illustration of the student in assessing the likelihood of fraud in the scenario of fraud triangle element (i.e. pressure and opportunity) is high and low as in the Fig. 2.

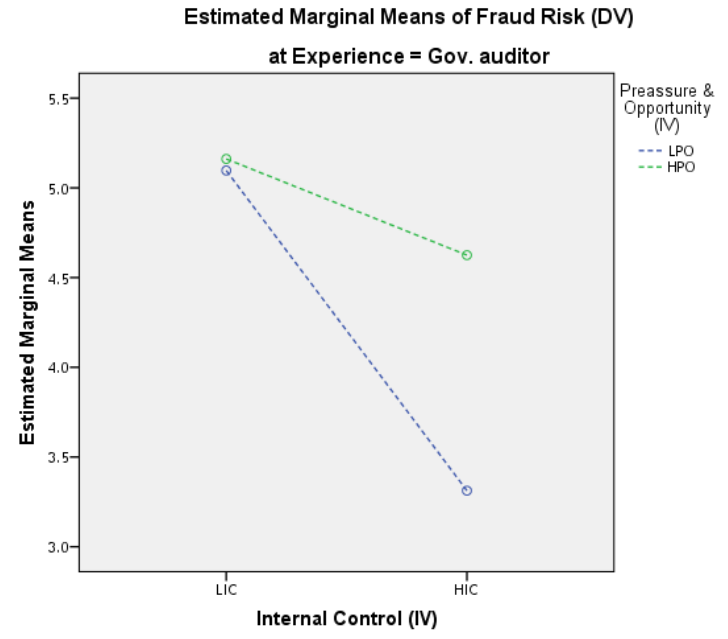

Fig. 3. Interaction between internal control framework, fraud triangle element and gov. auditor.

TABLE II: DESCRIPTIVE ANALYSIS FOR EXPERIMENT GROUP

\begin{tabular}{|c|c|c|c|c|c|}
\hline \multicolumn{6}{|c|}{ Dependent Variable: Fraud Risk (DV) } \\
\hline $\begin{array}{c}\text { Internal } \\
\text { Control (IV) }\end{array}$ & $\begin{array}{c}\text { Preassure \& } \\
\text { Opportunity (IV) }\end{array}$ & Experience & Mean & SD & $\mathrm{N}$ \\
\hline \multirow{9}{*}{ LIC } & \multirow{3}{*}{ LPO } & Student & 5.63 & 1.215 & 35 \\
\hline & & Gov. auditor & 5.10 & 1.326 & 31 \\
\hline & & Total & 5.38 & 1.286 & 66 \\
\hline & \multirow{3}{*}{ HPO } & Student & 6.11 & .932 & 35 \\
\hline & & Gov. auditor & 5.16 & 1.734 & 31 \\
\hline & & Total & 5.67 & 1.439 & 66 \\
\hline & \multirow{3}{*}{ Total } & Student & 5.87 & 1.102 & 70 \\
\hline & & Gov. auditor & 5.13 & 1.531 & 62 \\
\hline & & Total & 5.52 & 1.367 & 132 \\
\hline \multirow{9}{*}{ HIC } & \multirow{3}{*}{ LPO } & Student & 4.13 & 1.100 & 32 \\
\hline & & Gov. auditor & 3.31 & 1.176 & 32 \\
\hline & & Total & 3.72 & 1.201 & 64 \\
\hline & \multirow{3}{*}{ HPO } & Student & 4.62 & 1.497 & 32 \\
\hline & & Gov. auditor & 4.62 & 1.314 & 32 \\
\hline & & Total & 4.62 & 1.397 & 64 \\
\hline & \multirow{3}{*}{ Total } & Student & 4.38 & 1.327 & 64 \\
\hline & & Gov. auditor & 3.97 & 1.403 & 64 \\
\hline & & Total & 4.17 & 1.375 & 128 \\
\hline \multirow{9}{*}{ Total } & \multirow{3}{*}{ LPO } & Student & 4.91 & 1.379 & 67 \\
\hline & & Gov. auditor & 4.19 & 1.533 & 63 \\
\hline & & Total & 4.56 & 1.494 & 130 \\
\hline & \multirow{3}{*}{ HPO } & Student & 5.40 & 1.436 & 67 \\
\hline & & Gov. auditor & 4.89 & 1.546 & 63 \\
\hline & & Total & 5.15 & 1.507 & 130 \\
\hline & \multirow{3}{*}{ Total } & Student & 5.16 & 1.424 & 134 \\
\hline & & Gov. auditor & 4.54 & 1.573 & 126 \\
\hline & & Total & 4.86 & 1.527 & 260 \\
\hline
\end{tabular}


While for Gov. Auditor, when fraud triangle element (i.e. pressure and opportunity) are low they marked the likelihood of fraud risk as high when internal control is low $(M=5.10)$. When internal control framework is high, Gov. Auditor marked the likelihood of fraud risk as low $(M=3.31)$. While in the scenario of high fraud triangle element (i.e. pressure and opportunity), Gov. Auditor marked the likelihood of fraud risk high when the internal control framework low $(M=$ 5.16). When internal control framework high, they marked the likelihood of fraud risk as low $(M=4.62)$ in high fraud triangle element (i.e. pressure and opportunity). The illustration of the Gov. Auditor in assessing the likelihood of fraud in the scenario of fraud triangle element (i.e. pressure and opportunity) is high and low as in the fig. 3. Means and standard deviation for each group in assessing the likelihood of fraud risk show in Table II and Table III.

\section{TABLE III: ANOVA TABLE FOR EXPERIMENT GROUP}

\begin{tabular}{|c|c|c|c|c|c|c|}
\hline & $\begin{array}{l}\text { Tests of B } \\
\text { Dependent }\end{array}$ & tweer & $\begin{array}{l}\text { n-Subjects } \\
\text { le: Fraud F }\end{array}$ & $\begin{array}{l}\text { Effects } \\
\text { Risk (DV) }\end{array}$ & & \\
\hline Source & $\begin{array}{c}\text { Type III Sum } \\
\text { of Squares }\end{array}$ & df & $\begin{array}{l}\text { Mean } \\
\text { Square }\end{array}$ & $\mathrm{F}$ & Sig. & $\begin{array}{c}\text { Partial Eta } \\
\text { Squared }\end{array}$ \\
\hline $\begin{array}{l}\text { Corrected } \\
\text { Model }\end{array}$ & $177.742^{\mathrm{a}}$ & 7 & 25.392 & 15.021 & .000 & .294 \\
\hline Intercept & 6068.273 & 1 & 6068.273 & 3589.745 & .000 & .934 \\
\hline ic & 114.459 & 1 & 114.459 & 67.710 & .000 & .212 \\
\hline po & 22.632 & 1 & 22.632 & 13.388 & .000 & .050 \\
\hline position & 21.396 & 1 & 21.396 & 12.657 & .000 & .048 \\
\hline ic $*$ po & 6.460 & 1 & 6.460 & 3.821 & .052 & .015 \\
\hline ic $*$ position & 1.832 & 1 & 1.832 & 1.084 & .299 & .004 \\
\hline po * position & .621 & 1 & .621 & .367 & .545 & .001 \\
\hline $\begin{array}{l}\text { ic * po * } \\
\text { position }\end{array}$ & 6.171 & 1 & 6.171 & 3.650 & .057 & .014 \\
\hline Error & 425.993 & 252 & 1.690 & & & \\
\hline Total & 6739.000 & 260 & & & & \\
\hline $\begin{array}{l}\text { Corrected } \\
\text { Total }\end{array}$ & 603.735 & 259 & & & & \\
\hline
\end{tabular}

a. R Squared $=.294($ Adjusted R Squared $=.275)$

\section{DISCUSSION AND CONCLUSION}

This study investigates whether internal control framework or fraud triangle element (i.e. pressure and opportunity) will mostly influences the auditor in assessing the likelihood of fraud risk. As suggest by the result, Gov. Auditor use more internal control framework in assessing the likelihood of fraud risk. This is because auditor perceive that weak internal control and wrong attitude towards the importance of internal control by management will cause greater risk for the fraud to be occur [5]. Plus if the quality of internal control is poor, auditor will increased the audit evidence and procedure because incidence of fraud appear to be higher [7]. Even though the fraud triangle element will help the auditor to improve their ability in assessing the likelihood of fraud risk, they still cannot leave their basic understanding in the internal control framework for the fraud triangle element alone [3]. However Gov. Auditor still considers the fraud triangle element when assessing the likelihood of fraud risk as a second consideration after the internal control framework.

As a conclusion, more training need by auditor on how to use the fraud triangle element in assessing the likelihood of fraud risk. Auditor able to identify the fraud triangle element during the performing the audit but the level of usage of fraud triangle element still low. As [11] find there's an obvious gap between what is perceived to be important and what is actually being used as fraud risk indicators by the practicing practitioners. Beside of the training, auditor need to be exposed into a various task for them to get hand on experienced in detecting fraud because the more experienced auditors are generally more likely to detect fraud than inexperienced auditors [6].

\section{ACKNOWLEDGMENT}

Thanks to Universiti Teknologi MARA Malaysia and Ministry of Education for funding this project under the Accounting Research Institute Research Grant Scheme.

\section{REFERENCES}

[1] P. Francis, "How to Prevent Fraud," Accountants Today, no. August, pp. 56-58, 2013.

[2] Association of Certified Fraud Examiner, "Report to the nations on occupational fraud and abuse," 2012.

[3] R. E. LaSalle, "Effects of the fraud triangle on students' risk assessments," Journal of Accounting Education, vol. 25, no. 1-2, pp. 74-87, Jan. 2007.

[4] ISA 240, "The auditor's responsibilities relating to fraud in an audit of financial statements," International Federation of Accountants (IFAC), pp. 1-39, February 2008.

[5] M. Smith, N. Omar, S. I. Z. S. Idris, and I. Baharuddin, "Auditors' perception of fraud risk indicators: Malaysian evidence," Managerial Auditing Journal, vol. 20, no. 1, pp. 73-85, 2005.

[6] G. D. Moyes and I. Hasan, "An empirical analysis of fraud detection likelihood," Managerial Auditing Journal, vol. 11, no. 3, pp. 41-46, 1996.

[7] K. Rae and N. Subramaniam, "Quality of internal control procedures: Antecedents and moderating effect on organisational justice and employee fraud," Managerial Auditing Journal, vol. 23, no. 2, pp. 104-124, 2008.

[8] S. Dellaportas, "Conversations with inmate accountants: Motivation, opportunity and the fraud triangle," Accounting Forum, Oct. 2012.

[9] KPMG Malaysia, Fraud Survey Report 2009, 2009.

[10] Pricewaterhouse Coopers, Fraud in the Public Sector, 2010.

[11] N. Omar and H. F. Mohammad Din, "Fraud diamond risk indicator: An assessment of its importance and usage," Science and Social Research (CSSR 2010), 2010, July 2005, pp. 607-612.

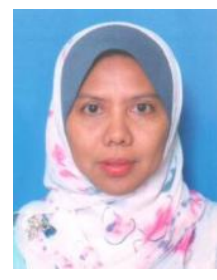

Zuraidah Mohd Sanusi is currently the deputy director of the Accounting Research Institute (ARI), Universiti Teknologi MARA and lecturer of Faculty of Accountancy. Her current research interest is in the area of forensic accounting, financial criminology, auditing and corporate governance.

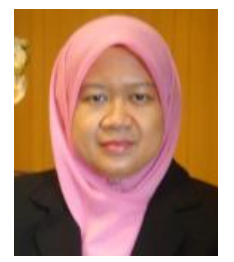

Norhayati Mohamed is currently holding the position of director at the Programme Management Office (PMO), Ministry of Education. Some of her responsibilities include overseeing the monitoring of the implementation of the National Higher Education Strategic Plan (PSPTN), in addition to planning and executing the strategic communication processes amongst all relevant stakeholders. She is seconded to the Ministry from Universiti Teknologi MARA (UiTM). Dr Norhayati's research interest is in the area of financial accounting, dividend policy, corporate governance and forensic accounting. She held the position of the Journal Administrator, and later promoted to Managing Editor for the Malaysian Accounting Review (MAR), an internationally refereed journal, indexed by ERA (Excellence in Research for Australia). 


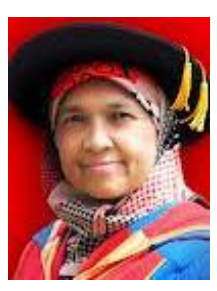

Normah Omar is currently the director of the Accounting Research Institute (ARI), Universiti Teknologi MARA. Her current research interest is in the area of forensic accounting and financial criminology. Recently ARI has been recognized as a national centre of excellence under the Ministry of Higher Education (HICoE). Her current research interests are in the areas of: Anti-Money Laundering \& Counter Financing of Terrorism (AML-CFT); Fraud Risk Indicators; Corporate Integrity System; Fraud Prevention Mechanism and Islamic Microfinancing.

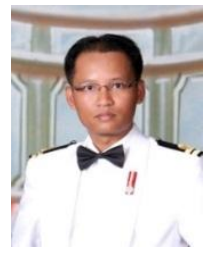

Mohd Daniel Mohd Nassir is currently a Ph.D. student at the Faculty of Accountancy, University Teknologi MARA. His is on leave from the Malaysian Audit General Office, Putrajaya, Malaysia. 